\title{
KONFLIK TOKOH DALAM KABA SIUMBUIK MUDO
}

\section{Charisma Pratama}

\begin{abstract}
This article describes character confict analysis of kaba Siumbuik Mudo. On this object, there is manjapuik malu or manjapuik baleh which reflect the main character's pride. Using structural and qualitative method, the result shows that the main characters (Umbuik Mudo and Puti Galang Banyak) has high ego which brings conflicts on them.
\end{abstract}

Key word: character conflict, intrinsic, stuctural, kaba, Siumbuik Mudo

\section{Pengantar}

Konflik adalah percekcokan, perselisihan, atau pertentangan di dalam cerita rekaan atau drama (pertentangan antara dua kekuatan, pertentangan dalam diri satu tokoh, pertentangan antara dua tokoh, dan sebagainya) (Chaniago, 2002:35). Pada dasarnya, konflik berasal dari bahasa Latin yaitu configere yang berarti 'saling memukul'. Secara sosiologis, konflik diartikan sebagai suatu proses sosial antara dua orang atau lebih (bisa juga kelompok) dimana salah satu pihak berusaha menyingkirkan pihak lain dengan menghancurkannya atau membuatnya tidak berdaya.

Menurut Nurgiyantoro, konflik (conflict) adalah suatu kejadian yang tergolong penting yang dapat berupa peristiwa fungsional, utama, atau kernel yang merupakan unsur esensial dalam pengembangan plot. Pengembangan plot dalam sebuah karya naratif akan dipengaruhi untuk tidak ditentukan oleh wujud dan isi konflik, bangunan konflik yang ditampilkan. Konflik menyarankan pada pengertian sesuatu yang bersifat tidak menyenangkan yang terjadi dan dialami oleh tokoh-tokoh yang terlibat dalam cerita (1995:122). Sementara itu, Wellek dan Warren (1993) lebih melihat konflik sebagai sesuatu hal yang bersifat dramatik, yang mengacu pada pertarungan antara dua kekuatan yang seimbang dan 
menyiratkan adanya aksi dan aksi balasan.

Pada dasarnya, konflik dilatarbelakangi oleh perbedaan ciri-ciri yang dibawa individu dalam suatu interaksi, perbedaan-perbedaan tersebut diantaranya adalah menyangkut ciri fisik, kepandaian, pengetahuan, adat istiadat, keyakinan, dan lain sebagainya. Dengan dibawasertanya ciri-ciri individual dalam interaksi sosial, konflik merupakan situasi yang wajar dalam setiap masyarakat dan tidak satu masyarakat pun yang tidak pernah mengalami konflik antaranggotanya atau dengan kelompok masyarakat lainnya. Konflik hanya akan hilang bersamaan dengan hilangnya masyarakat itu sendiri.

Dengan demikian, konflik dalam pandangan kehidupan yang normal bukan dalam cerita menyarankan pada konotasi negatif atau suatu tindakan yang tidak menyenangkan. Oleh sebab itu, orang lebih suka memilih untuk menghindari konflik dan menghendaki kehidupan yang tenang tanpa adanya suatu permasalahan.

Berbeda halnya dengan cerita yang diteksnaratifkan. Dalam teks, tanpa adanya konflik di dalam suatu cerita tidak akan ada artinya karena konfliklah yang membangkitkan semangat pembaca untuk membaca teks karya sastra. Hal di atas mengindikasikan bahwa pengarang menangkap gejala yang hidup di tengah masyarakat pada masa tertentu dan menggambarkan secara jujur realitas kehidupan masyarakat dalam karya sastra.

Dalam sastra tradisional Minangkabau, kaba biasa disebut curito, yang artinya cerita. Kata khabar berubah dalam ucapan Minangkabau menjadi kaba, dalam perkembangan selanjutnya kaba disebut curito. Mulanya kaba adalah semacam bentuk penyampaian kabar baik atau buruk. Agar kaba tersebut mempunyai daya yang kuat, maka dijalinlah kaba tersebut dalam bentuk cerita yang diberi nama kaba curito (Udin, 1987:8).

Begitu banyak judul kaba yang ada di Minangkabau, salah satunya berjudul kaba Simbuik Mudo. Kaba ini ditulis oleh Sjamsudin Sutan Radjo Endah dan diterbitkan pertama kali pada tahun 1960 oleh Pustaka Indonesia. Kemudian mengalami revisi dan percetakan ulang pada tahun 2004 dan 2006 oleh Kristal Multi Media Bukittinggi.

Kaba Siumbuik Mudo adalah kaba yang bercerita tentang manjapuik malu atau manjapuik baleh yang dilakukan oleh Umbuik Mudo akibat penghinaan yang dilakukan oleh Puti Galang Banyak. Penghinaan tersebut tidak hanya menyinggung perasaan satu orang (Umbuik Mudo), tetapi 
juga menyinggung perasaan orang tua Umbuik Mudo yaitu Amai Sarijah.

Adapun alasan penulis menjadikan Kaba Simbuik Mudo sebagai objek penelitian adalah untuk mencari dan mengkaji konflik yang terjadi dalam Kaba Siumbuik Mudo. Tindakan ini penting agar permasalahan yang menjadi objek penelitian lebih fokus dan terarah, hingga mencapai suatu hasil yang diinginkan. Tentunya dengan menghubungkannya dengan karakteristik dari masing-masing tokoh. Hal ini perlu dilakukan karena tokoh merupakan bagian dari penggerak dan menciptakan konflik, yang kemudian berkembang hingga menjadi klimaks.

Beragammya permasalahan yang tampak dalam Kaba Siumbuik Mudo, tidak terlepas dari peristiwa yang dialami oleh tokoh itu sendiri. Konflik tersebut berhubungan dengan kejadian yang dialami langsung oleh pribadi dari tokoh itu sendiri. Dengan demikian, penulis menganalisis lebih jauh kaba Siumbuik Mudo ini terbatas pada konflik tokoh yang terdapat dalam kaba Siumbuik Mudo.

\section{Landasan Teori}

Salah satu konsep dasar yang menjadi ciri khas dari teori struktural menurut Pradopo (2000:71) adalah adanya anggapan bahwa di dalam dirinya sendiri karya sastra merupakan suatu struktur yang otonom yang dapat dipahami sebagai sebagai suatu kesatuan yang bulat dengan unsurunsur pembangunnya yang saling berhubungan.

Analisis struktural dalam karya sastra dapat dilakukan dengan mengidentifikasi, mengkaji dan mendeskripsikan fungsi dan hubungan antar unsur intrinsik. Pada mulanya dilakukan identifikasi yang kemudian dideskripsikan melalui keadaan peristiwa, tokoh dan penokohan, latar, sudut pandang, dan lain-lain. Setelah dijelaskan fungsi dari masingmasing unsur tersebut dalam menunjang makna keseluruhannya, maka secara bersama akan membentuk sebuah totalitas kemaknaan yang padu, misalnya hubungan antar peristiwa yang satu dengan peristiwa yang lainnya, kaitannya dengan pemplotan yang tak selalu kronologis, kaitannya dengan tokoh dan penokohan, dengan latar dan sebagainya (Nurgiyantoro, 1995:37).

Dengandemikian, analisisstruktural bertujuanuntukmengembangkan dan memaparkan secara cermat, teliti dan sedalam mungkin keterkaitan dan keterjalinan semua anasir-anasir dan aspek karya sastra yang menghasilkan makna menyeluruh (Teeuw, 1984:135). Yang terpenting adalah bagaimana 
menunjukkan hubungan antarunsur tersebut dan sumbangan apa yang diberikan terhadap tujuan estetik serta makna yang ingin dicapai. Hal ini perlu dilakukan karena karya sastra merupakan sebuah struktur yang kompleks dan unik, namun hal inilah yang membedakan antara karya yang satu dengan karya yang lainnya, salah satunya adalah konflik (Nurgiyantoro, 1995:38).

Konflik sangat berperan penting di dalam sebuah cerita. Tanpa adanya konflik, maka dapat dipastikan cerita tersebut terkesan datar dan monoton. Konflik menyarankan pada pengertian tentang sesuatu yang bersifat tidak menyenangkan, yang terjadi dan dialami oleh tokoh di dalam cerita. Konflik adalah sesuatu yang dramatik, mengacu pada pertarungan antara dua kekuatan yang seimbang dan menyiratkan adanya aksi dan aksi balasan (Wellek \& Waren, 1993). Dengan demikian, konflik dalam pandangan kehidupan manusia normal-wajar-faktual, artinya bukan dalam cerita, menyaran pada konotasi yang negatif, sesuatu yang tidak menyenangkan.

Maka dapat disimpulkan bahwa pada dasarnya konflik tersebut saling berkaitan, saling menyebabkan terjadinya peristiwa satu dengan peristiwa yang lainya mengalami suatu proses (pertikaian), dan dapat terjadi dan dialami oleh seorang tokoh cerita dalam waktu yang bersamaan, walau tingkat intensitasnya mungkin saja tidak sama. Tingkat kompleksitas konflik yang ditampilkan dalam sebuah karya fiksi, dalam banyak hal menentukan kualitas dan kemenarikan karya itu. Bahkan, jika menulis cerita sebenarnya tidak lain adalah untuk membangun dan mengembangkan konflik itu sendiri.

Bentuk peristiwa dalam sebuah cerita, dapat berupa peristiwa fisik ataupun batin. Peristiwa fisik dapat melibatkan aktifitas fisik dimana terdapat interaksi antara seorang tokoh cerita dengan sesuatu yang diluar dirinya: tokoh lain atau lingkungan. Peristiwa batin adalah sesuatu yang terjadi dalam batin, hati, seorang tokoh. Kedua bentuk peristiwa tersebut saling berkaitan, saling menyebabkan terjadinya satu dengan yang lain. Bentuk konflik sebagai bentuk kejadian, dapat pula dibedakan ke dalam dua kategori yatu konflik fisik dan konflik batin, konflik eksternal (external conflict) dan konflik internal (internal conflict) (Nurgiyantoro, 1995:123).

Konflik eksternal adalah konflik yang terjadi antara seorang tokoh dengan sesuatu yang di luar dirinya, mungkin dengan lingkungan alam mungkin lingkungan manusia. Dengan demikian, konflik eksternal dapat dibedakan kedalam dua kategori, yaitu konflik fisik (physical conflict) dan 
konflik sosial (social conflict) (Nurgiyantoro, 1995:124).

Konflik fisik (atau disebut juga: konflik elemental) adalah konflik yang disebabkan adanya perbenturan antara tokoh dengan lingkungan alam. Misalnya, konflik dan atau permasalahan yang dialami seorang tokoh akibat adanya banjir besar, kemarau panjang, gunung meletus, dan sebagainya. Konflik sosial adalah konflik yang disebabkan oleh adanya kontak sosial antar manusia, atau masalah-masalah yang muncul akibat adanya hubungan antar manusia. Ia dapat berwujud masalah perburuhan, penindasan, percekcokan, peperangan, atau kasus-kasus hubungan sosial lainya di dalam masyarakat (Nurgiyantoro, 1995:124).

Di pihak lain, konflik internal (atau: konflik kejiwaan) adalah konflik yang terjadi dalam hati, atau jiwa seorang tokoh di dalam cerita. Dengan kata lain, konflik internal merupakan konflik yang dialami oleh manusia dengan dirinya sendiri, dengan kata lain ia lebih dititik beratkan pada permasalahan interen seorang manusia. Misalnya, terjadi pertentangan antara dua keinginan, keyakinan, pilihan yang berbeda, harapan-harapan, atau masalah-masalah lainnya (Nurgiyantoro, 1995:124).

\section{Metode dan Teknik}

Tahapan penelitian yang penulis lakukan adalah pengumpulan dan klasifikasi data, analisis, dan penyimpulan. Data diperoleh dengan cara melakukan studi kepustakaan dan mencari bahan-bahan yang mendukung penelitian. Data yang didapatkan terdiri dari dua kategori yaitu data primer dan data sekunder. Data primer didapatkan melalui teks yang mengandung konflik berupa kutipan atau pun dialog yang terdapat dalam teks Kaba Siumbuik Mudo. Data sekunder berupa bahan-bahan pustaka yang relevan dan mendukung penelitian ini.

Data-data yang telah terkumpul kemudian diklasifikasi dan dianalisa dengan menggunakan teori struktural sehingga masalah yang diajukan sebelumnya dapat terpecahkan dan tujuan penelitian ini dapat tercapai. Data-data tersebut berupa peristiwa-peristiwa yang terjadi dan berhubungan dengan konflik tokoh yang menjadi objek penelitian. Langkah selanjutnya adalah menyimpulkan hasil penelitian dari analisis yang telah dilakukan. 


\section{Pembahasan}

\subsection{Tokoh Penokohan}

Tokoh dalam Kaba Siumbuik Mudo adalah perwatakan tokoh bulat. Tokoh bulat yaitu tokoh yang memiliki suatu watak tertentu yang dapat diformulakan, dimana penampilan watak dan tingkah laku dari tokoh tersebut bermacam-macam (Nurgiyantoro, 1995:181-188).

Konflik tokoh melibatkan lima orang (pelaku) di dalam cerita yaitu Umbuik Mudo, Puti Galang Banyak, Amai Sarijah, Amai Sigalang, Bapak Sigalang. Hal ini melalui pertimbangan intensitas kemuncuannya. Tokohtokoh tersebut kemudian dikategorikan berdasarkan perwatakan dan perkembangan wataknya sesuai dengan jalan cerita yang ada.

Umbuik Mudo tokoh utama yang menjadi pusat cerita. Tokoh ini berkembang sesuai dengan permasalahan yang terjadi di alur cerita. Umbuik Mudo seorang anak yang baik dan patuh terhadap perintah orang tua. Di samping itu, ketaatannya dalam beribadah dan memperdalam ilmu agama menjadikannya menjadi seorang anak yang menjadi teladan bagi masyarakat di tempat dia berada. Tekadnya yang kuat dalam memperdalam ilmu agama menjadikannya seorang yang ahli dan fasif dalam melantunkan ayat suci Al-Quran dan makna yang terkandung di dalamnya. Tekad yang kuat tersebut dapat dilihat dalam kutipan di bawah ini.

"lah mangaji si Umbuik Mudo, banyaklah kitab nan ta kaji, banyaklah surek nan tabaco, banyaklah lagu nan dapek, hatinyo tarang nan bak suluah, kajinyo bak cando aia lalu, lorong kasuaronyo, nyariang lai garuak lai, garuaknyo garuak manih, namun malagu siumbuik mudo, urang bajalan jadi baranti, buruang tabang jadi hinggok" (hlm. 16-17).

(sudah mengaji si Umbuik Mudo, banyaklah kitab yang terpelajari, surat yang terbaca, lagu yang didapatnya, hatinya terang seperti suluh, pelajarannya seperti air lalu, tentang akan suaranya, nyaring dan serak, seraknya manis terdengar, sehingga ketika si Umbuik Mudo bernyanyi, orang jalan jadi berhenti, burung terbang menjadi hinggap).

Perubahan sikap Umbuik Mudo mulai terlihat setelah dia mulai jatuh cinta kepada Puti Galang Banyak. Namun, dengan alasan belum siap menikah dan hidup berumah tangga Puti Galang Banyak menolak. Akibatnya, Umbuik Mudo tersinggung. Amarah yang berlebihan 
menghilangkan akal sehat seseorang sehingga dia lupa akan Tuhan. Tindakan Umbuik Mudo tersebut secara psikologis berdampak buruk pada diri seseorang. Niat manjapuik malu atau manjapuik baleh kepada Puti Galang Banyak telah membutakan hati dan pikirannya.

Tokoh Puti Galang Banyak adalah seorang wanita yang angkuh. Hal ini disebabkan karena parasnya yang cantik dan menjadi wanita idaman bagi setiap laki-laki yang memandangnya, tak terkecuali Umbuik Mudo.

"rancak nan bukan alang-alang, mukonyo bak bulan panuah, kaniangnyo kiliran taji, hiduangnyo pucuak talutuak, talingonyojarek tatahan, bibianyo limau sauleh, karek kukunyo bulan ka habih, karetanyo bintang batabua, dipiliah dalam dipiliah, dipiliah dalam nan batujuah, si Bungsu rancak sakali, banamo Puti Galang Banyak, cinto hati dek bapaknyo, pamenan urang sakampuangnyo, duduak inyo di kanan si Umbuik, sanan bakato Puti Galang Banyak, banyaklah urang nan mangaji, banyaklah urang nan malagu, tuanku lai mualim lai, satu tidak denai dangakan, surang tidak denai acuahkan, tadanga lagu tuan Umbuik, baureh raso jantuang denai, tasingkok kiro-kiro denai, lah nyalang pandangaran denai, dek itu mangko denai turun" (hlm. 25).

(begitu indahnya, muka seperti bulan penuh, keningnya amat licin, hidungnya mancung, telinga jarek tertahan, bibirnya tipis, potong kukunya seperti bulan sabit, keretanya bintang bertabur, dipilih dalam dipilih, dipilih dalam bertujuh, si bungsu cantik sekali, bernama Puti Galang Banyak, cinta hati bapaknya, idola orang sekampungnya, duduk dia di kanan si Umbuik, sambil berkata Puti Galang Banyak, banyaklah orang yang mengaji, banyaklah orang yang bernyanyi, tuanku yang memulai, pertama tidak saya dengarkan, sendiri tidak saya acuhkan, terdengar lagu tuan Umbuik, berdetak jantung saya, terbuka kira-kira saya, telah nyaring telinga saya, karena itu saya turun).

Sikap dan keangkuhan Puti Galang Banyak juga terlihat ketika dia menghina Umbuik Mudo karena masalah status sosialnya yang tidak setara. Status sosial sering kali membuat orang lupa bahwa setiap orang memiliki harga diri yang patut untuk dijaga. Pelecehan ini dipertegas dengan sikap dan penolakan yang membuat Amai Sarijah sangat terhina tidak hanya harga diri sendiri tapi juga harkat dan martabat keluarganya.

Amai Sarijah adalah ibu Umbuik Mudo. Dia seorang ibu yang bijaksana dan penyayang terhadap anak-anak maupun keluarganya. Seorang ibu pada dasarnya merupakan tempat untuk menampung segala aspirasi, inspirasi, dan pelipur dikala duka bagi anak-anaknya. 
Kasih sayangnya terhadap anaknya Umbuik Mudo, justru menjadi malapetaka bagi dirinya sendiri. Hal ini terlihat ketika Puti Galang Banyak menghina harkat dan harga diri keluarganya. Sebagai seorang ibu, dia telah berusaha semaksimal mungkin untuk mewujudkan keinginan dari anaknya. Hal ini ditandai dengan kedua kalinya dia mendapat cercaan dan hinaan dari Puti Galang Banyak yang terus melakukan penolakan atas diri Umbuik Mudo. Kesedihan Amai Sarijah ini dapat dilihat dalam kutipan di bawah ini.

"kununlah Amai si Umbuik, lah bak ayam kanai lokok, hati gata mato digauik, bajalan jo hati ibo, bajalan tahantak-hantak, bajalan tataguntagun.

Kapundan kuliknyo manih

Pucuak sibayua-bayua tinggi

Baunduang-unduang malah manangih

Apo kiro-kiro denai kini

Ya Allah, Ya Rasullallah, baalah untuang denai nangko, satampan ikolah anak, sajombang ikolah rupo, rancak lai patuik lai, tumbuah cacek baadokan, urang indak manenggang awak, mangalah bak itu bana, garak Allah sudah di denai" (hlm. 43-44).

(kononlah ibu si Umbuik, seperti kanai pukul, hati gatal mata digaruk, berjalan dengan hati iba, berjalan terhentak-hentak, berjalan tertegun-tegun.

Kepundan kulitnya manis

Pucuknya sangatlah tinggi

Terisak-isak mehanan tangis

Apa kiranya saya sekarang

Ya Allah, ya Rasulullah, bagaimana untung saya ini, setampan inilah anak saya, sebagus inilah rupanya, sudah pantas dibilang bagus, malah timbul hinaan, orang tidak memandang kita, mengapa begitu betul, kehendak Allah tiba pada saya.

Bapak Sigalang adalah ayah Puti Galang Banyak. Dia seorang ayah yang tegas dan penyayang kepada keluarga maupun anak-anaknya. Hal ini terlihat ketika Puti Galang Banyak meminta ayahnya untuk menemui Umbuik Mudo. 
"bakato bapak si Galang, manolah buyuang Umbuik Mudo, kok buliah pintak jo pinto, palakukan malah kandak denai, buyuang kawin kini juo, iyo jo Puti Galang Banyak, usah diulang duo kali, nan sakarang kini nanko, mamintak ambo sungguah-sungguah, elok dipakai buruak dibuang, kok salah nak kami timbang, kok utang nak kami bayia, asal lai pintak nak balaku, buyuang kawin kini nanko jo si Galang Banyak" (hlm. 86-87).

(berkatalah bapak si Galang, wahai buyung Umbuik Mudo, jika boleh saya meminta, berlakukan hendaknya kehendak saya, kamu menikah sekarang juga, dengan Puti Galang Banyak, jangan sampai saya minta dua kali, sekarang ini juga, saya meminta dengan sungguh-sungguh, baik dipakai buruk dibuang, jika salah biar kami timbang, jika berhutang biar kami bayar, asal kehendak bisa berlaku, kamu menikah sekarang juga dengan Puti Galang Banyak).

Sifat dan karakteristik Amai Galang Banyak hampir sama dengan Amai Sarijah. Sifat seorang ibu tetaplah sama yakni sama-sama mencintai dan menyayangi keluarga maupun anak-anaknya. Sifatnya yang lemah lembut dan bersahaja menimbulkan kedamaian dan keharmonisan di dalam keluarganya. Hal ini dapat dilihat dalam kutipan di bawah ini.

\begin{abstract}
"Birawari Amai si Galang, urang cadiak bijaksano, bakato sambia manangih, manangih ma isak-isak, oi upiak Puti Galang Banyak, Kabakan bana habih-habih usah anak maandok-andok, apo bana lah nan sakik, apo ubuk kan nan dicari, apo bana kandak anak, denai mamintak kato putuih, katokan bana kato hati anak, jikok tidak anak banakan juo, indak dikatokan jaleh-jaleh, den amuak badan ko kini, nak sanang bana hati anak" (hlm. 75).
\end{abstract}

(tentang Amai Sigalang, orang cerdik bijaksana, berkata sambil menangis, menangis terisak-isak, wahai engkau PutiGalang Banyak, beritakan benar dengan jelas, jangan anak malu mengungkapkan, jangan anak sembunyi-sembunyi, apa betul yang sakit, apa obat yang akan dicari, apa benar maunya anak, saya memintak kata putus, katakan benar mau hati anak, jika tidak anak benarkan juga, tidak dikatakan jelas-jelas, saya hancurkan badan ini, biar senang benar hati anak).

Namun, di balik sikap Amai Galang yang bersahaja dia tidak dapat mengontrol dan mendidik anak bungsunya dengan baik. Dari segi ucapan dan sikap, sudah mencerminkan dia bukan orang yang beradat dan tidak terdidik. Puti Galang Banyak tidak dapat membedakan dengan siapa dia berbicara. Penyesalan Amai Galang ini dapat terlihat ketika kondisi anaknya 
sudah tidak memungkinkan lagi. Hal ini dapat dilihat dalam kutipan di bawah ini.

"oi upiak Puti Galang Banyak, kabakan bana habih-habih, usah anak mambuni-buni, usah anak maandok-andok, apo bana nan lah sakik, apo ubek nan ka dicari, apo bana kandak anak, denai mamintak kato putuih, katokan bana kato hati anak, jikok tidak anak banakan juo, indak dikatokan jaleh-jaleh, den amuak badan ko kini-kini, nak sanang bana hati anak" (hlm. 75).

(wahai engkau Puti Galang Banyak, beritakan benar dengan jelas, jangan anak malu mengungkapkan, jangan anak sembunyisembunyi, apa betul yang sakit, apa obat yang akan dicari, apa benar maunya anak, saya memintak yang pasti, katakan benar mau hati anak, jika tidak anak benarkan juga, tidak dikatakan jelas-jelas, saya hancurkan badan ini, biar senang benar hati anak).

\subsection{Latar}

Latar tempat mengisyaratkan pada lokasi terjadinya peristiwa yang diceritakan dalam sebuah karya fiksi. Unsur tempat tersebut dapat berupa tempat-tempat dengan nama-nama tertentu, inisial tertentu dan lokasi tertentu. Latar Kaba Siumbuik Mudo digambarkan oleh pengarang pada suatu daerah yang terdapat di Minangkabau pada masa dahulu yaitu di ranah Kampuang Tibarau yang terletak di daerah Pesisir Selatan provinsi Sumatera Barat.

Lokasi ini merupakan tempat asal Umbuik Mudo. Di tempat ini dia dididik dan dibesarkan, serta mendapatkan pengajaran yang cukup berharga dalam hidupnya yaitu sebuah pendidikan dari Amai Sarijah tentang akan pentingnya makna hidup, menghormati orang lain, dan pentingnya mempelajari ilmu pengetahuan tidak terkecuali dalam ilmu agama.

"manyambah Siumbuik Mudo, mamintak ampun ka amainyo, iyo bajalan hanyo lai, kama lah inyo bajalan, iyo ka ranah Simulanggang, ka ranah Kampuang Aua, mangaji inyo di sanan, di surau Tuanku Panjang Jangguik" (hlm. 15).

(menyembah si Umbuik Mudo, meminta ampun ke ibunya, lalu berjalan dia lagi, ke ranah Simulanggang, ranah kampung Aua, mengaji dia disitu, di surau Tuanku Panjang Jangguik). 
Selain kampuang Tibarau, juga terdapat beberapa tempat yang menjadi tujuan dari Umbuik Mudo dalam mencari jati diri, maupun pengalaman dalam hidup diantaranya Ranah Kampuang Aua di surau Tuanku Panjang Jangguik yaitu tempat dimana Umbuik Mudo belajar ilmu agama dan pendidikan Islam secara baik, serta Kampuang Aua yaitu tempat kediamaman Puti Galang Banyak sekeluarga tinggal bersama keenam orang kakaknya.

Latar waktu berhubungan dengan "kapan" terjadinya peristiwaperistiwa yang diceritakan dalam sebuah karya fiksi. Masalah "kapan" tersebut biasanya dihubungkan dengan waktu faktual, waktu yang ada kaitannya atau dapat dikaitkan dengan peristiwa sejarah dan masalah waktu dalam karya naratif dapat bermakna ganda: di satu pihak menyarankan pada waktu penceritaan, waktu penulisan cerita, dan dipihak lain menunjukan pada waktu dan urutan waktu yang terjadi dan dikisahkan dalam cerita (Nurgiyantoro, 1995:230).

Latar waktu dapat berupa hitungan jam, nama-nama hari, bulan dan peredaran matahari. Penjelasan tentang latar waktu, disampaikan oleh pengarang secara ekplisit misalnya pada waktu siang hari, "hari nan sadang tangah hari (hari yang sedang tengah hari), sadang bagalanggang matohari (matahari sedang tingginya), sadang bunta bayang-bayang (sedang buntal bayang-bayang)" (hlm. 9). Pada waktu malam hari juga diungkapkan dengan "hari nan samalam-malam nan tun (hari yang sedang tengah malam), laruik malam mako talalok (larut malam maka tertidur)" (hlm. 85). Pengungkapan sore hari menjelang senja adalah dengan "lah patang candonyo hari (sepertinya hari telah petang), patang bajawek dangan sanjo" (petang berjawab dengan senja)" (hlm. 18).

Latar waktu dalam cerita ini sama seperti biasa diantaranya; wakatu tangah hari (waktu tengah hari), samalam-malam nan tun (waktu malam), dan lah patang candonyo hari (waktu sore menjelang senja). Waktu berdasarkan peredaran matahari misalnya, pado hari nan sahari nan tun (pada hari itu juga), hari barisuak (besok hari), patang pagi siang malam (petang pagi siang malam), paneh sarupo mambalah banak (panas seperti membelah otak), sadang baggalanggang matohari (matahari sedang tingginya). Hitungan hari dengan jumlah hari, jumlah bulan dan jumlah tahun diungkapkan dengan, alah sahari duo hari (telah sehari dua hari), hari barisuak (besok hari), habih pakan baganti pakan (habis pekan baganti pekan), alah sahari pajalanan (telah sehari perjalanan), lah sampai bilangan bulan (telah sampai bilangan bulan), alah sabulan duo bulan (telah sebulan dua bulan), alah satahun inyo mangaji (telah 
setahun dia mengaji), nan satahun duo tahun iko (yang setahun dua tahun ini).

Latar sosial menyarankan pada hal-hal yang berhubungan dengan prilaku kehidupan sosial masyarakat di suatu tempat yang diceritakan dalam karya fiksi. Tata cara kehidupan sosial masyarakat mencakup berbagai masalah yang cukup komplek. Ia dapat berupa kebiasaan hidup, adat istiadat, tradisi, keyakinan, pandangan hidup, cara berpikir dan bersikap, dan lain-lain. Disamping itu latar sosial juga berhubungan dengan status sosial tokoh yang bersangkutan, misalnya rendah, menengah, atas (Nurgiyantoro, 1995:233-234). Status sosial seringkali menjadi pemicu timbulnya konflik dan tidak jarang berakhir dengan "dendam" yang berujung dengan salah satu diantara mereka menjadi korban akibat dari konflik tersebut. Salah satunya adalah Puti Galang Banyak yang terdapat dalam Kaba Siumbuik Mudo.

"koknyo tuan Umbuik Mudo, siang tak jadi angan-angan, malam tak menjadi mimpi, kok elok bana tuan Umbuik, lah tau denai di eloknyo, elok di kain basalang, kok gadang bana tuan Umbuik Mudo, lah tau denai di gadangnyo, gadang tabaok di ruwehnyo, kok kayo tuan Umbuik Mudo, lah tau denai di kayonnyo, kayo dek ameh pambawoan bapaknyo, ka galang kaki denai tak sampai" (hlm. 43).

(walaupun dia seorang Umbuik Mudo, siang tidak jadi anganangan, malam tidak menjadi mimpi, jika baik betul tuan Umbuik, sudah tau saya dibesarnya, besar telihat diruasnya, jika kaya tuan Umbuik Mudo, sudah tau saya akan kayanya, kaya karena emas peninggalan bapaknya, untuk gelang kaki saya, belumlah sampai).

Kaba Siumbuik Mudo ini berlatar sosial Minangkabau. Tempat terjadinya peristiwa tersebut masih dapat dijumpai pada saat sekarang ini seperti Ranah Simalunggang, Ranah Kampuang Aua, dan Kampuang Tibarau. Tempat terjadinya peristiwa dalam kaba ini dapat dijumpai di daerah Sungai Tunu, Kecamatan Balai Lasa, di kampung Pungasan (Pesisir), provinsi Sumatera Barat. Dalam lingkungan tersebut mereka menjalankan fungsinya sebagai masyarakat dan penggerak dari setiap peristiwa-peristiwa yang terjadi. Dalam lingkungan masyarakat, terdapat kultur dan ragam status sosial dari masyarakat.

kama lah inyo bajalan, iyo ka ranah Simulanggang, ka ranah Kampuang Aua, mangaji inyo di sanan, di surau Tuanku Panjang Jangguik" (hlm. 
15).

(kemana dia berjalan, iya ke ranah Simalunggang, ke ranah Kampung Aua, mengaji dia disana, di surau Tuanku Panjang Jangguik).

Dalam kaba ini, para tokoh berasal dari kalangan masyarakat biasa, tetapi diatur melalui suatu hukum dan undang-undang yang berlaku dalam adat itu sendiri. Latar sosial ini juga tidak terlepas dari persoalan "manjapuik malu atau manjapuikkan baleh" yang dilakukan Umbuik Mudo terhadap Puti Galang Banyak. Pada dasarnya setiap peristiwa yang terjadi merupakan suatu proses dan cerminan dari masyarakat itu sendiri. Intinya adalah bagaimana seseorang itu dapat mengendalikan emosi dalam dirinya dan dapat bersikap positif dalam menyikapi suatu masalah, tentunya dengan hati yang ikhlas dan jiwa yang tenang.

\subsection{Tema}

Pada hakikatnya tema merupakan ide sentral dari suatu cerita. Menurut Aminuddin, tema adalah ide yang mendasari suatu cerita sehingga berperan juga sebagai pangkal tolak pengarang dalam memaparkan karya yang diciptakanya (2009:91). Dengan demikian, tema menjadi dasar pengembangan seluruh cerita, maka tema pun bersifat menjiwai seluruh bagian cerita tersebut.

Tema Kaba Siumbuik Mudo adalah manjapuik malu atau manjapuik baleh seorang tokoh kepada tokoh lain yang telah menghina dan menjatuhkan harga diri pribadi maupun keluarganya. Tema ini dapat dilihat melalui rangkaian peristiwa yang terjadi. Secara keseluruhan, tema dalam teks Kaba Siumbuik Mudo secara keseluruhan berbicara tentang moral, etika, dan sifat seseorang. Tindakan ini direalisasikan melalui jalan pintas dengan membuat seruling yang sudah diberi mantera, kemudian ditujukan kepada seseorang yang dianggap bersalah, dan layak mendapat hukuman seperti yang dialami oleh Puti Galang Banyak.

Tema ini terus berkembang dan menjadi suatu hal yang menarik. Hal ini dapat dilihat melalui tindakan dan serangan yang terus dilancarkan oleh Umbuik Mudo kepada Puti Galang Banyak yang berdampak secara psikologis terhadap diri seseorang. Dampak dari tindakan Umbuik Mudo ini dapat dilihat dalam kutipan di bawah ini. 
"lah sahari sasudah itu, lah duo hari antaronyo, lah sakik si Galang Banyak, sakik nan tak jago lai, nasi dimakan raso sakam, ayia diminum sambiluan, banyaklah urang nan maubek, banyaklah tawa nan takanakkan, nan panyakik batambah dalam, lah ilang aka bapaknyo, lah mabuak hati mandehnyo, mancaliak parasaian si Galang Banyak, indak tantu nan ma nan sakik, badan bak raso bayang-bayang, kapalo raso karangkah, darah denai tasirok-sirok, nasi dimakan raso duri, ayia diminum pahik-pahik, denai nan taragak di Umbuik Mudo, ka ranah Kampuang Tibarau, sakik kok lai kasanang" (hlm. 69-70).

(sehari setelah itu, telah dua hari diantaranya, maka sakitlah si Galang Banyak, sakit yang tidak bangun lagi, nasi dimakan terasa sekam, air diminum bak sembilu, banyaklah orang yang datang mengobati, banyaklah mantera yang dibacakan, yang penyakit bertambah dalam, telah hilang akal bapaknya, telah mabuk hati ibunya, melihat penderitaan si Galang Banyak, tidak tentu dimana yang sakit, badan seperti bayang-bayang, kepala terasa pecah, darah saya terkejut-kejut, nasi dimakan terasa duri, air diminum sangat pahit, saya rindu pada Umbuik Mudo, ke ranah Kampung Tibarau, jika sakit maka akan terobati).

\subsection{Hubungan Antarunsur}

Dari pembicaraan berbagai unsur yang telah dilakukan di atas, ternyata antarunsur tersebut saling berkaitan. Pada dasarnya, semua hal yang terlibat menjadi acuan dalam pembentukan tema (ide pokok). Tokoh berfungsi sebagai penggerak konflik di dalam teks kaba, dimana Umbuik Mudo berperan sebagai tokoh utama yang berkonflik dengan tokoh lainnya yaitu: Puti Galang Banyak, Amai Sarijah, Bapak Galang, Amai Galang. Penghinaan yang dilakukan oleh Puti Galang Banyak telah menjatuhkan harga diri Umbuik Mudo yang menimbulkan rasa malu. Peristiwa ini mendorong Umbuik Mudo untuk bersikap membela diri pribadi dan juga keluarga.

Tokoh tersebut kemudian dijalani dengan plot yang beralur maju. Di mana alur yang mengandung konflik terus bergerak dari peristiwa satu ke peristiwa yang lainnya hingga mencapai klimaks. Peristiwa ini berlatar di Minangkabau yang masih dapat dijumpai pada saat sekarang ini seperti Ranah Simalunggang, Ranah Kampuang Aua, dan Kampuang Tibarau. Tempat terjadinya peristiwa dalam kaba ini dapat dijumpai di daerah Sungai Tunu, di Kampung Punggasan (Pesisir), Provinsi Sumatera Barat. Dalam lingkungan tersebut mereka menjalankan fungsinya sebagai masyarakat dan penggerak dari setiap peristiwa yang terjadi. Sedangkan 
amanat berisi tentang pesan moral yang ingin disampaikan pengarang. Pesan itu berupa agar seorang perempuan bisa menjaga sikap maupun ucapannya supaya tidak menyakiti hati orang lain, seperti yang dilakukan Puti Galang Banyak.

\subsection{Konflik Tokoh dalam Kaba Siumbuik Mudo}

Konflik yang menjadi acuan dalam Kaba Siumbuik Mudo ini adalah konflik internal yaitu konflik yang terjadi di dalam hati, atau jiwa seorang tokoh di dalam cerita. Dengan kata lain konflik internal adalah konflik yang dialami oleh manusia dengan dirinya sendiri dan lebih di titik beratkan pada permasalahan interen seorang manusia. Tidak menutup kemungkinan tokoh-tokoh yang lain muncul dan menjadi pemicu terjadinya konflik.

Konflik tokoh pada dasarnya mengindikasikan pada peristiwaperistiwa apa saja yang dialami oleh para tokoh, tidak hanya tertuju pada tokoh utama saja, namun juga ditujukan pada tokoh-tokoh yang terlibat di dalam cerita. Artinya peranan setiap tokoh dalam membangun cerita itu penting, karena dengan kehadirannyalah menimbulkan ketegangan maupun kontroversi yang dapat membangun cerita hingga mencapai klimaks.

Konflik tokoh dalam Kaba Siumbuik Mudo dapat dilihat melalui karakteristik Umbuik Mudo yang mengalami perubahan secara perlahan menghilangkan kesadaran dan akal sehatnya. Peristiwa ini juga berimbas kepada beberapa orang tokoh yang terlibat di dalam cerita baik secara langsung maupun secara tidak langsung. Tokoh-tokoh tersebut yaitu Puti Galang Banyak, Amai Sarijah, Amai Sigalang, dan Bapak Sigalang.

Konflik-konflik dalam kaba ini terus berkembang sejalan dengan tindakan dan upaya-upaya yang dilakukan Umbuik Mudo untuk membalas sakit hatinya. Upaya ini diwujudkan melalui ritual yang dilakukannya yang kemudian berimbas pada seseorang yang akan dituju yaitu Puti Galang Banyak.

Konflik antara Puti Galang Banyak dengan Amai Sarijah diawali oleh sikap dan tindakan dari Amai Sarijah yang bermaksud untuk menikahkan anaknya Umbuik Mudo dengan Puti Galang Banyak. Namun, penolakan Puti Galang Banyak tersebut tidak mengurungkan niat Amai Sarijah untuk berusaha mewujudkan keinginan anaknya yang sangat mengharapkan pernikahan tersebut. Peristiwa ini berakhir dengan ucapan dan tindakan yang kurang menyenangkan dari seorang Puti Galang Banyak yang berakhir 
dengan perasaan kecewa dan penyesalan dari seorang Amai Sarijah.

Konflik antara Umbuik Mudo dengan Amai Sarijah diawali oleh hasrat dan keyakinan yang teguh dari seorang anak. Dalam hal ini, orang tua hanya bertugas menyampaikan keinginan anaknya kepada seorang gadis yang menjadi tambatan hatinya. Namun harapan dan keinginan tidak selalu dapat diwujudkan. Hanya saja Umbuik Mudo tidak mau menerima kenyataan kalau keinginannya tersebut tidak terpenuhi.

Amai Sarijah telah berusaha semampunya untuk menutupi peristiwa yang terjadi di rumah Puti Galang Banyak. Namun, di satu sisi dia harus menjelaskan permasalahan yang terjadi secara terperinci kepada anaknya. Ada kalanya permasalahan yang terjadi tidak harus dibicarakan atau disampaikan sedetail mungkin kepada orang lain atau kepada seorang anak. Tujuannya adalah untuk menjaga stabilitas dan mental si anak agar tidak labil dan menimbulkan efek yang kurang baik terhadap sikap dan karakteristik si anak.

Konflik antara Umbuik Mudo dengan Puti Galang Banyak pada dasarnya dipicu oleh tindakan yang kurang menyenangkan yang berakhir dengan dendam. Terkadang rasa sakit yang tidak dapat ditahan menimbulkan suatu reaksi yang tidak baik seperti yang dilakukan oleh Umbuik Mudo terhadap Puti Galang Banyak. Reaksi ini terus berlanjut pada suatu tindakan penganiayaan terhadap diri seseorang. Hal ini dapat dilihat dalam kutipan di bawah ini.

"anak mancacak anak mancacau, anak si ngiang-ngiang rimbo, anak dapek dalam samak, anak cenceng panaruhan, anak indak bapitunjuak,anak indak bapangajaran, luak awak dikaruahkannyo, baru mandanga nan bak nantun, manjanguah si Umbuik Mudo, tagak inyo ka nan tarang, bapantun si Umbuik Mudo.

Cumati talang biduri

Lantak sapanuah pamatang

Hari paneh alah babuni

Awak litak nan kuniang datang.

Mandanga pantun nan bak kian, mambangih si Galang Banyak, lalu dituruikkannyo sakali, diludahinyo si Umbuik Mudo, ditariaknyo parian, dihantamkannyo ka si Umbuik, nambek si Umbuik nan ka kanai, pariannyo lah tandeh pacah-pacah, diambiaknyo pulo labunyo, dihampehkannyo sakali, diilakkan dek si Umbuik, labu lah tandeh ramuak-ramuak" (hlm. 60-61). 
(anak tidak berguna, anak bunyi-bunyian dalam rimba, anak dapat dalam rimba, anak seratcancangan, anak yang tidak diberi petunjuk, anak yang tidak berpendidikan, lubuk saya dikeruhkan, sumur saya dikacaukannya, baru mendengar yang seperti itu, melihat si Umbuik Mudo, berdiri dia ketempat yang terang, berpantun si Umbuik Mudo:

\section{Cumati talang biduri}

Terletak sepanjang pematang

Hari panas sudah berbunyi

Saya letih yang kuning datang

Mendengar pantun yang seperti itu, marah si Galang Banyak, lalu diikutinya sekali, diludahinya si Umbuik Mudo, ditariknya parian, dihantamkan ke si Umbuik, jangankan si Umbuik akan kena, pariannya sudah pecah-pecah, diambilnya pula labunya, dihempaskannya sekali, dielakkan oleh si Umbuk, labu sudah pecah remuk-remuk).

Pernyataan di atas mulai terlihat suatu reaksi dan tindakan yang tidak semestinya terhadap seorang wanita. Reaksi ini begitu jelas ditujukan ketika seorang anak perempuan akan pergi mandi. Dalam aturan norma dan etika, jelas dia telah menyalahi aturan dan kodratnya sebagai seorang laki-laki yang berpendidikan. Dalam adat Minangkabau, seorang laki-laki seharusnya dapat menjaga sikap maupun tindakannya. Di dalam adat juga diajarkan akan pentingnya norma kesopanan dan sopan santun apalagi terhadap seorang perempuan yang akan pergi mandi.

Reaksi tersebut memperlihatkan bahwa Umbuik Mudo mulai kehilangan kendali maupun akal sehatnya terhadap suatu tindakan yang tidak diperkenankan bahkan dilarang oleh ajaran agama Islam maupun adat istiadat di Minangkabau. Sebagai seorang yang berbudaya dan memiliki pemikiran dan tingkat pendidikan yang cukup memadai, semestinya dia berpikir akan tindakannya. Namun ketika akal sehat mulai ditutupi oleh hasrat untuk menjerumuskan orang lain, secara otomatis dia tidak akan mendengarkan suara hati, maupun nasehat yang diberikan. Tindakan yang seperti ini justru sangat membahayakan apabila tidak dicegah sejak dini.

Konflik antara Puti Galang Banyak dengan ayahnya dipicu oleh hasrat dan keinginan dari Puti Galang Banyak untuk bertemu dengan Umbuik Mudo yang tidak kunjung terwujud. Tindakan demi tindakan mulai 
menimbulkan reaksi yang berlebihan. Hal ini diawali oleh sikap dan tingkah lakunya yang sangat bertentangan seperti dengan sengaja menghardik ayah kandungnya sendiri karena tidak dapat membawa Umbuik Mudo ke sisinya.

Pada dasarnya, konflik-konflik yang terjadi disebabkan karena banyaknya muncul permasalahan-permasalahan baikyang diakibatkan oleh lingkungan masyarakat maupun diakibatkan oleh ulah diri pribadi maupun orang lain. Hal ini juga diakibatkan karena kurangnya pengendalian dalam diri dan tidak adanya berupa saran dan masukan yang datang dari orangorang terdekat disekitarnya. Faktor- faktor penyebab terjadinya konflik adalah sebagai berikut:

1. Perbedaan individu, yang meliputi perbedaan pendirian dan perasaan.

Setiap manusia adalah individu yang unik. Artinya, setiap orang memiliki pendirian dan perasaan yang berbeda-beda satu dengan lainnya. Perbedaan pendirian dan perasaan akan sesuatu hal atau lingkungan yang nyata ini dapat menjadi faktor penyebab konflik sosial, sebab dalam menjalani hubungan sosial, seseorang tidak selalu sejalan dengan kelompoknya.

Pada dasarnya, lain manusia maka lain pula sifat dan pola pikirnya dan begitu pula dalam menyelesaikan suatu masalah. Ini membuktikan bahwa masing-masing individu memiliki cara tersendiri di dalam memberikan suatu penilaian terhadap barang suatu.

2. Perbedaan latar belakang status sosial sehingga membentuk pribadi-pribadi yang berbeda.

Seseorang sedikit banyaknya akan terpengaruh dengan pola-pola pemikiran dan pendirian kelompoknya. Pemikiran dan pendirian yang berbeda itu pada akhirnya akan menghasilkan perbedaan individu yang dapat memicu konflik. Perbedaan latar belakang ini jelas terlihat melalui perbedaan antara si kaya dengan si miskin yang meliputi status sosial seseorang. Dalam Kaba Siumbuik Mudo ini, jelas memperlihatkan bahwa status sosial Puti Galang Banyak lebih tinggi dibandingkan dengan Umbuik Mudo. Puti Galang banyak berasal dari keturunan yang serba berkecukupan baik dalam pemenuhan kebutuhan hidup maupun dalam masalah lainnya. Sementara Umbuik Mudo, hanyalah seorang anak yang berusaha untuk mencapai suatu tujuan hidup dan berusaha untuk meraihnya karena pada dasarnya 
tingkat kecukupan materil dalam keluarga Umbuik Mudo masih sangat jauh berbeda dari Puti Galang Banyak.

3. Perbedaan Kepentingan Tujuan Antara Individu atau Kelompok.

Manusia memiliki perasaan, pendirian maupun latar belakang kepentingan yang berbeda. Oleh sebab itu, dalam waktu yang bersamaan, masing-masing orang atau kelompok memiliki tujuan yang berbeda-beda. Karena perbedaan pandangan dan kepentingan inilah yang memicu terjadinya konflik. Setiap individu memiliki sikap dan pemahamannya tersendiri terhadap sesuatu hal baik secara langsung maupun secara tidak langsung. Perbedaan kepentingan ini jelas terlihat ketika Puti Galang Banyak menolak lamaran dari Umbuik Mudo.

Akibat konflik-konflik tersebut, muncul permasalahan dan pertikaianpertikaian yang terkadang menyisakan berbagai penderitaan ataupun permasalahan. Akibat konflik-konflik tersebut adalah sebagai berikut.

1. Keretakan hubungan antarkelompok yang bertikai.

Timbul perpecahbelahan antara Umbuik Mudo dengan Puti Galang Banyak. Hal ini ditandai dengan amarah yang memuncak akibat hinaan yang tidak dapat diterimanya. Rasa dendam dan amarah kadang kala membuat orang lupa dan kalap mata, sehingga melakukan sesuatu diluar batas kemampuannya. Keretakan hubungan inilah yang kemudian terus berkembang dan memuncak pada taraf titik konflik.

2. Perubahan kepribadian pada individu, misalnya timbulnya rasa dendam, benci, saling curiga, dan lain-lain.

Rasa dendam dan amarah yang tidak tertahan menimbulkan pemikiran buruk dan keinginan untuk mencelakakan orang lain dengan cara apapun. Tak jarang, sifat dendam membawa seseorang pada permasalahan yang panjang, yang bahkan tidak mampu terselesaikan dengan baik. Oleh karena itu, dalam ajaran agama Islam dendam itu dilarang apalagi untuk mencelakai orang lain. Untuk itu, dibutuhkan pondasi yang kuat di dalam diri, yakni dengan banyak berikhtiar dan berserah diri kepada-Nya.

3. Kerusakan harta benda dan hilangnya jiwa manusia.

Umbuik Mudo telah mencelakai orang lain. Tidak mau bertanggungjawab atas peristiwa yang menimpa Puti Galang Banyak, yang perlahan-lahan mulai hilang kendali, tenaga maupun akal sehat. Kejadian inilah yang banyak ditemui dalam kondisi sekarang ini. Mencari 
seseorang yang mau mempertanggungjawabkan perbuatannya sangatlah susah. Maka dari itu, sebelum melontarkan kata-kata kepada orang lain hendaklah difikirkan. Terkadang ada orang yang tersinggung atau tersakiti oleh ucapan dan tindakan yang kita lakukan. Pengendalian diri itu lebih penting untuk menghindari munculnya permasalahan-permasalahan baru yang akan berdampak buruk pada diri sendiri maupun pada orang lain.

\subsection{Penyelesaian Konflik}

Penyelesaian konflik dalam kaba Siumbuik Mudo ini terbatas pada timbulnya rasa bersalah dan minta maaf atas kesalahan yang telah dilakukannya. Hal ini terlihat ketika Umbuik Mudo menyampaikan pesanpesan terakhirnya supaya dimakamkan di dekat makam Puti Galang Banyak.

Peristiwa tersebut mengindikasikan Umbuik Mudo merasa bersalah karena telah melakukan penganiayaan pada diri seorang perempuan yakni pada diri Puti Galang Banyak. Penganiayaan tersebut berdampak pada hilangnya nyawa seseorang yang bahkan menimbulkan luka dan duka pada orang-orang di sekitarnya. Meninggal karena sakit itu merupakan hal yang wajar, tetapi meninggal karena perbutan dan tindakan dari seseorang itu merupakan suatu sikap yang mendahulukan kodrat dan kekuasaan Tuhan. Dengan kata lain, Umbuik Mudo mendapat pelajaran berharga dari apa yang dia lakukan.

\section{Penutup}

Berdasarkan uraian dan analisis yang telah dilakukan sebelumnya, maka dapat disimpulkan bahwa Kaba Siumbuik Mudo adalah kaba yang menggambarkan pentingnya harga diri yang berhubungan langsung dengan tokoh. Peristiwa yang terjadi tidak lepas dari adanya hubungan sebab-akibat. Hal ini dipicu karena masing-masing tokoh (Umbuik Mudo dan Puti Galang Banyak) memiliki ego yang tinggi, dimana keduanya tidak ada yang mau mengalah serta tidak ada yang mau dikalahkan. Atas dasar inilah timbulnya suatu perselisihan yang berujung pada terhinanya harga diri seseorang, yang secara tidak langsung berkaitan dengan pencemaran nama baik keluarga seseorang (Umbuik Mudo).

Salah paham tak jarang menjadi pemicu timbulnya konflik seperti yang terjadi dalam Kaba Siumbuik Mudo yakni melalui Puti Galang Banyak. Dampak yang terjadi atas timbulnya perselisihan antara Umbuik Mudo 
dengan Puti Galang Banyak tidak hanya berakibat hilangnya nyawa seseorang (Puti Galang Banyak), tetapi juga menimbulkan konflik terhadap masing-masing tokoh. Seperti konflik Puti Galang Banyak dengan Amai Sarijah, konflik Umbuik Mudo dengan Amai Sarijah, konflik Puti Galang Banyak dengan Bapak Galang, dan konflik Puti Galang Banyak dengan Amai Galang.

\section{Daftar Pustaka}

Awwali, Muchlis dan Hasanadi. 2004. "Diktat Pengantar Kajian Kesusastraan". Padang: Universitas Andalas.

Chaniago, Amran YS. 2002. Kamus Lengkap Bahasa Indonesia. Bandung: CV. Pustaka Setia.

Damono, Sapardi Djoko. 1978. Sosiologi Sastra: Sebuah Pengantar Ringkas. Jakarta : Pusat Pembinaan dan Pengembangan Bahasa, Departemen Pendidikan dan Kebudayaan.

Sakti, Surya Darma Eka 2008. “Teks Randai Umbuik Mudo Karya Musra Dahrizal". Skripsi Sarjana Fakultas Sastra Universitas Andalas. Padang

Djamaris, Edward. 2001. Pengantar Sastra Rakyat Minangkabau. Jakarta: Yayasan Obor Indonesia.

Endraswara, Suwardi. 2003. Metodologi Penelitian Sastra Minangkabau. Yogyakarta: FBS Universitas Negeri Yogyakarta.

Fananie, Zainuddin. 2002. Telaah Sastra. Surakarta: Universitas Muhammadiyah.

Faruk. 1994. Pengantar Sosiologi Sastra: dari Strukturalisme Genetik sampai Post-Modernisme. Yogyakarta: Pustaka Pelajar (Anggota IKAPI).

Junus, Umar. 1984. Kaba dan Sistem Sosial Minangkabau Suatu Problema Sosiologi Sastra. Jakarta: Balai Pustaka.

Moleong, Lexy J. 2007. Metode Penelitian Kualitatif. Bandung: PT. Remaja Rosdakarya.

Nurgiyantoro, Burhan. 1995. Teori Pengkajian Fiksi. Yogyakarta: Gadjah Mada University Press.

Rahardo, Reza. 2006. “Konflik Diri Tokoh Utama dalam Kaba Siumbuik Mudo". Skripsi Sarjana Fakultas Sastra Universitas Andalas. Padang.

Semi, Atar. 1988. Anatomi Sastra. Jakarta: Angkasa Raya.

Siswantoro. 2005. Metode Penelitian Sastra: Analisis Psikologis. Surakarta: Muhammadiyah University Press.

Sofia, Adib dan Sugihastuti. 2003. Feminisme dan Sastra (Menguak Citra Perempuan dalam Layar Terkembang). Bandung: Kartasis.

Sudjiman, Panuti dan Aart Van Zoest. 1991. (Penyunting) Seba-serbi Semiotika. Jakarta: Gramedia.

Sutan Radjo Endah, Sjamsuddin. 2006. Kaba Siumbuik Mudo. BukittinggiSumatera Barat: CV. Kristal Multi Media.

Suriasumantri, S. Jujun. 1995. Filsafat Ilmu Sebuah Pengantar Populer. Jakarta: Pustaka Sinar Harapan.

Teeuw. A. 1984. Sastra dan Ilmu Sastra: Pengantar Teori Sastra. Jakarta: Pustaka Jaya. 
Charisma Pratama

Udin Syamsudin, dkk. 1987. Struktur Kaba Minangkabau. Jakarta: Pusat Pembinaan dan Pengembangan Budaya.

Wellek Rene dan Austin Warren. 1993. Teori Kesusastraan, Jakarta: PT. Gramedia Pustaka Utama. 